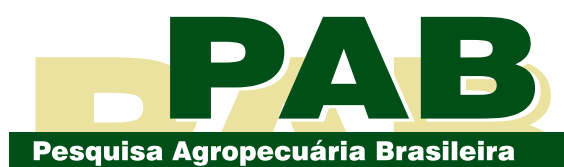

ISSN 1678-3921

Journal homepage: www.embrapa.br/pab

For manuscript submission and journal contents, access: www.scielo.br/pab

\section{Invasive wild boars and native mammals in agroecosystems in the Atlantic Forest of Western Brazil}

\begin{abstract}
The objective of this work was to estimate an index of the relative biomass per species, in a medium to large-sized mammal community, as well as to determine how the introduced wild boar (Sus scrofa) fits into this index, and to verify if the occupancy of sites by domestic dogs interferes with those of wild boars and how much the periods of dogs' activity overlap those of wild boars. The biomass/effort index was measured for each native mammal species and for the introduced wild boar, in two surveyed farms in Brazil's Western Atlantic Forest range, through the use of camera trappings that were also used to verify if dogs and wild boar overlap in space and activity time. Wild boars seem to dominate the community, just a few years after their presence was first recorded in the region. Surprisingly, several native endangered mammal species persist in the highly modified landscape of the studied areas, but their population trends are still unknown. Wild boars and dogs generally occupy the same areas; however, they do not overlap in activity time, which is an indicative that it is unlikely that the dogs can effectively protect the crops.
\end{abstract}

Index terms: Canis familiaris, Sus scrofa, activity time, community composition, niche overlap.

\section{Javalis invasores e mamíferos nativos em agroecossistemas na Mata Atlântica do Oeste do Brasil}

\begin{abstract}
Resumo - O objetivo deste trabalho foi estimar um índice de biomassa relativa por espécie, em uma comunidade de mamíferos de médio a grande porte, assim como determinar como o javali (Sus scrofa) invasor se ajusta a esse índice, e verificar se a ocupação de locais por cães interfere na ocupação por javalis e quanto o período de atividade dos cães se sobrepõe ao do javali. O índice de biomassa/esforço foi medido para cada espécie de mamífero nativo e também para o javali invasor, em duas fazendas em área de Mata Atlântica do Oeste do Brasil, por meio de armadilhas fotográficas, que também foram usadas para estimar a sobreposição espacial e o período de atividade de cães e javalis. Os javalis parecem dominar a comunidade de mamíferos, poucos anos depois que sua presença na região foi registrada. Surpreendentemente, várias espécies ameaçadas de mamíferos nativos ainda persistem na paisagem altamente modificada das áreas estudadas, porém suas tendências populacionais são ainda desconhecidas. Javalis e cães ocupam em geral as mesmas áreas; no entanto, não se sobrepõem no período de atividade, o que é indicativo de que é improvável que os cães possam efetivamente proteger os cultivos.
\end{abstract}

Termos de indexação: Canis familiaris, Sus scrofa, período de atividade, composição da comunidade, sobreposição de nicho. 


\section{Introduction}

In Brazil, large portions of pristine and secondary grow th of native vegetation have been lost to agricultural development and cattle ranching, especially in the Atlantic Forest and Cerrado domains (Hirota, 2019). The western portion of the Atlantic Forest extends into the state of Mato Grosso do Sul, Brazil, that is an area strongly impacted by agriculture and cattle ranching (Cáceres et al., 2008). Since the 1970s, the landscape in this region has been transformed by deforestation to clear the land for the cultivation of soybean and corn (Barbo et al., 1980) and, more recently, of sugarcane. The possible refuges for native wildlife in these agroecosystems are narrow strips of riverine forest and some scattered forest fragments. About $21.5 \%$ of Brazil's native mammals occur in the state of Mato Grosso do Sul (Cáceres et al., 2008), and about 49\% of them are nonflying mammals weighing more than one kilogram (Cáceres et al., 2008). Whether these medium and large-sized mammals persist in such highly fragmented ecosystems is a matter of controversy. Moreover, the chances for the persistence of native mammals could be reduced by the presence of a large, invasive alien species.

The feral hog (Sus scrofa) is considered one of the world's 100 worst alien invasive species (Lowe et al., 2000) because of the economic losses and environmental damage it has caused in countries where it was introduced (Pimentel et al., 2005; Deberdt \& Scherer, 2007; Hegel \& Marini, 2013). Nowadays, feral hogs are found worldwide, except for the Antarctica (Long, 2003). They cause direct economic losses because they attack crops, notably corn plantations, and prey on livestock, as well as indirect losses due to the usually high costs of population control programs, and losses associated with the sanitary risk to the livestock industry (Pimentel et al., 2005; Deberdt \& Scherer, 2007). In USA, the world's largest corn producer, with 370,960 thousand tons in 2018 (Abimilho, 2019), crop damage and control costs per pig correspond to about $\$ 300$ per year, and the total annual cost of damage and control of feral hogs amounts to at least 1.5 billion dollars (Pimentel et al., 2005). In Brazil, hogs were probably introduced in the early years of the Portuguese colonization (Crosby, 1993), and feral populations may have become locally established. "Pure" wild boars were introduced in waves, the first one from Uruguay, dating back to 1989, followed by the release of animals imported from Canada in 1996/1997 (Deberdt \& Scherer, 2007). According to the administrative act Instrução Normativa n. ${ }^{\circ} 3,2013$ of Ibama - the Brazilian institute of environment and renewable natural resources, all free-ranging Sus scrofa hybrids are considered "wild boars" except for those living in the Pantanal region, which have been known to occur there for at least two centuries (Desbiez et al., 2011). Invasive wild boars have been found in the agroecosystems of Mato Grosso do Sul state since at least 2006 (Deberdt \& Scherer, 2007).

There are no national or regional estimates of economic losses caused by feral hogs, or even of feral hog numbers in Brazil. However, considering that Brazil is the world's third largest corn producer (94,500 thousand tons in 2018) and the second largest corn exporter, reaching about 29,000 thousand tons in 2018 (Abimilho, 2019), therefore, these losses may be very significant. In fact, Pedrosa et al. (2015) estimated a loss of nearly US $\$ 357,000$, in a single agribusiness enterprise operating in São Paulo state, Brazil. This information can be considered an indicator of the potential economic impact of feral hogs in the country. Also, the Brazilian swine business earns 1.5 billion dollars annually from international markets, and the invasion of feral pigs may put that market at risk (Pedrosa et al., 2015). The World Organization for Animal Health (OIE) has recently established stricter procedures to certify a country or state member as free of classical swine fever (CSF) (OIE, 2013), and also now requires detailed information from its member countries about possible contact between feral hogs and domestic pigs raised on farms. Therefore, information on the abundance and distribution of feral hogs, their relationships with native species and their environmental and economic impacts is still urgently needed to underpin control and contingency programs and strategies in Brazil (Pedrosa et al., 2015). Farmers in Mato Grosso do Sul state believe that the presence of dogs prevents invasive wild boars from attacking their grain crops. Therefore, they let their domestic dogs run loose in the plantations, especially during the pre-harvest period, in an attempt to create a fear landscape to the hogs, minimizing the crop damages. However, so far, no investigation has focused on any aspect of the interaction between domestic dogs and feral pigs or wild boars in the agroecosystems of Mato Grosso do Sul state. 
The objective of this work was to estimate an index of the relative biomass per species, in a medium to largesized mammal community, as well as to determine how the introduced wild boar fits into this index, and to verify if the occupancy of sites by domestic dogs interferes with those of wild boars and how much the periods of dogs' activity overlap those of wild boars.

\section{Materials and Methods}

Camera trapping surveillances were conducted on two farms located in Western Brazil (in the municipality of Rio Brilhante, in the state of Mato Grosso do Sul), from April 10 to August 01, 2014. The farm Carro de Boi (CDB) $\left(21^{\circ} 54^{\prime} 28.39^{\prime \prime} \mathrm{S}, 54^{\circ} 13^{\prime} 25.69^{\prime \prime} \mathrm{W}\right)$ and the

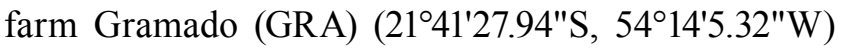
are located about $24 \mathrm{~km}$ apart from each other (Figure 1). The climate in the region is tropical wet, with cold dry (April to September) and warm rainy periods (October to March), mean annual temperature of $20-22^{\circ} \mathrm{C}$, and annual rainfall of $1,400-1,700 \mathrm{~mm}$ (Oliveira et al., 2000). The farms are located in the westernmost portion of the Atlantic Forest in Brazil, near the transition with the Cerrado domain (Hirota, 2019).

To obtain a rough estimate of the proportion of the study area that still has a native forest cover, GoogleEarth Pro (7.1.2.2041) images from 2012 were used as a reference to classify the vegetation, and RapidEye 5-meter resolution images, recorded in 2013 (Google Earth Pro, 2013), were used to create the vegetation maps. The land cover was classified into forest, wetland, water, and agricultural areas in a $5 \mathrm{~km}$ buffer around the center of each farm (Figure 1).

Camera traps (Bushnell Trophy Cam 8MP 119435) were used to monitor the medium ( $\geq 1 \mathrm{~kg}$ ) to largesized mammals in 22 plots in the farms. The area monitored by the cameras at CDB was about 10.7 $\mathrm{km}^{2}$, and the average distance between cameras was $1,668 \mathrm{~m}$ ( $\mathrm{SD}=779$, ranging from 266 to $3,347 \mathrm{~m})$, while at GRA, it was nearly $5 \mathrm{~km}^{2}$, and the mean distance between sample sites was $1,669 \mathrm{~m}(\mathrm{SD}=639$, varying from 132 to $3,250 \mathrm{~m}$ ). Camera traps were set to operate for 10-151-day periods, resulting in a sampling effort of 1,344 camera trap*days. The camera traps were checked once a week to replace the batteries and download the data stored in their memory cards. Most of the cameras were set to take photos every five seconds for twenty-four hours per day, adjusted to high-resolution and medium sensitivity to movements. Some cameras were programmed to record 7-second videos with 5 -second intervals between recordings. A threshold of 24 hours between photos and videos of the same species taken from a given camera was used to consider them independent. The cameras were installed along the edges, or within the riverine forests, forest patches, and cultivated land (soybean or corn).

The number of pictures taken of each species was weighted by the capture effort, defined by the number of surveillance days multiplied by the number of active camera traps. The mean group size and animal biomass (Emmons \& Feer, 1990; Redford \& Eisenberg, 1992; Eisenberg \& Redford, 1999; OliveiraSantos et al., 2011) were used to estimate an index of relative biomass, defined as the biomass/effort for each recorded species, divided by the total recorded biomass/effort. Most of these analyses were performed using the $\mathrm{R}$ version 3.3.0 software package ( $\mathrm{R}$ Core Team, 2016). To ensure that the effort was sufficient to assess the richness of the study site, the bootstrapped accumulation curve, estimated by the "poolaccum" function in vegan (Oksanen et al., 2016), was examined.

Also, the Presence version 6.4 program (Hines, 2006) was used to develop an occupancy model, to investigate if wild boars and domestic dogs co-occur, or avoid each other in space (plots) in the study area. The data were analyzed based on two-day intervals. The one-season approach for two species was used to model $\psi \mathrm{A}, \psi \mathrm{B}, \varphi, \mathrm{pA}, \mathrm{pB}, \mathrm{rA}, \mathrm{rB}$, where $\mathrm{A}$ is the occurrence of wild boars, and $\mathrm{B}$ is the occurrence of dogs. The parameter psi $(\psi)$ is the occupancy probability by both species, phi $(\varphi)$ is the species interaction factor, $p$ is the detectability of species, and $r$ is the probability of one species being detected when both are present at the plot (Mackenzie et al., 2002).

The time of the day when wild boars and domestic dogs were photographed was used to evaluate their activity patterns, modelled as a kernel density circular function (Oliveira-Santos et al., 2013), to estimate the activity overlap between these species. This function is similar to the kernel estimator of utilization distribution, which is usually employed to estimate animal home ranges. The function estimates isopleths that account for a given proportion of the whole probability function (for instance, 50 or 95\%). Thus, a $95 \%$ activity isopleth means the time interval in which 
$95 \%$ of the animal activity occurs. The function also returns the isopleth sections, when one would expect the two species to be active simultaneously, that is, the activity overlap (Oliveira-Santos et al., 2013), which can vary from zero to one (that is, no overlap to total overlap in a given isopleth).

\section{Results and Discussion}

Twenty-two percent of the GRA farm and its surroundings is covered by forest, from which $9.73 \%$ by wetlands, and $66.38 \%$ destined for crop production, while in the $\mathrm{CDB}$ farm and its surroundings, forest comprises $12.83 \%$ of the area, wetlands cover $8.16 \%$, and $76.85 \%$ is destined for crop production. This situation indicates the extent of the loss of natural habitat. The forest remnants in both areas consist mostly of riparian forest, which are protected by Brazilian law, and very few forest fragments are distant from streams and rivers (Figure 1). The areas under cultivation are used intensively for soybean crops (in summer), with rotation with corn (in winter) or, more recently, sugarcane (year-round).

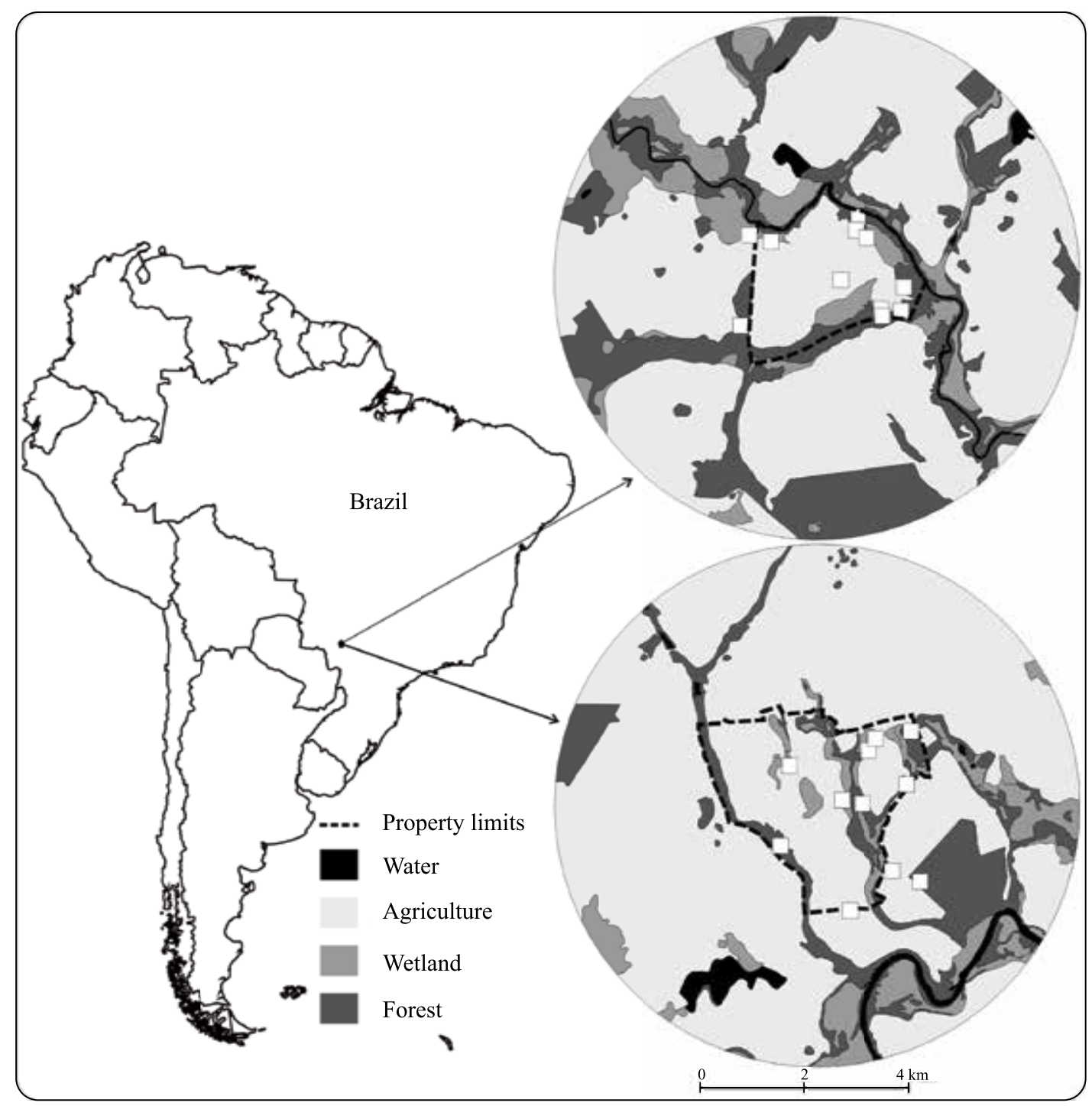

Figure 1. Land cover map, in a $5 \mathrm{~km}$ buffer around the center of Gramado farm (above) and Carro de Boi farm (below), in the municipality of Rio Brilhante, Mato Grosso do Sul state, Brazil. The white squares represent the positions of the camera trap sites, from April 10 to August 01, 2014. 
Despite the extensive change in land cover in the study area, it is in compliance with Brazilian regulations establishing a mandatory conservation of $20 \%$ of every rural property as Legal Reserve Areas (LRA), plus narrow strips of riparian forest along rivers, streams, springs, and other water bodies as Permanent Preservation Areas (PPA). Among the vegetation domains in Mato Grosso do Sul state, Atlantic Forest is the most impacted one by economic activities, and only $11,2 \%$ of its original cover is still standing in the state (Hirota, 2019). The Atlantic Forest occurs on relatively fertile soils, in comparison with other regions in the state of Mato Grosso do Sul, and this region shows the most intensive agricultural development (Zoneamento..., 2009).

A total of 1,344 independent records of mammals were obtained from camera traps. However, due to the poor quality of some of the photos, or because no characteristic parts of the animals were recorded, species identifications are not reliable in 187 of these pictures. Twenty-three free-ranging mammal species plus domestic dogs appeared in the pictures, out of which 22 were native species. The bootstrap model, applied only to these 22 native species, suggested that the asymptotic species richness would be about 23 species, and that our sample had roughly reached the asymptotic richness (Figure 2). The introduced wild boar was the most photographed species, with 32.6 pictures/100 days*camera, followed by the tapir (27.3 pictures/100 days*camera) and, taken together these images corresponded to $59.9 \%$ of all pictures, including those in which the recorded species could not be identified. Seven of the 22 native species are listed as vulnerable in the Brazilian list of threatened species (Brasil, 2014), and four are in the red list of the International Union for Conservation of Nature (IUCN, 2014) (Table 1).

The species richness recorded in the present study corresponds to over $50 \%$ of the total number of medium and large-sized terrestrial mammals known to occur in Mato Grosso do Sul state (Cáceres et al., 2008). At first glance, this proportion could be considered high, since there has been sufficient time for the local extinction process to take place, given the extent of habitat and landscape modification and the probable poaching pressure. Poaching in the Atlantic Forest has caused local extinctions of large-bodied mammals in regions of Brazil that were developed long before in southern Mato Grosso do Sul state (Cullen Jr. et al., 2000).

Agriculture was introduced in the region in the early 1970s, and by the 1980s, intensive soybean farming already covered about 800,000 hectares (Barbo et al., 1980), suggesting decades of ecosystem disruption associated with deforestation. However, other studies in disturbed areas of Atlantic Forest have found similar medium to large-sized mammals richness (Dotta \& Verdade, 2011; Cassano et al., 2012). In the present study, several species still comprise functional groups at several levels of the trophic chain, suggesting some degree of community integrity and the maintenance of some key ecological processes in these agroecosystems. Additionally, the relatively large number of mammal species detected in these agroecosystems indicates that the PPA and LRA zones are still capable of fulfilling their role, as established by Brazilian laws, despite the complete lack of knowledge about population sizes and trends. This was also pointed by Dotta \& Verdade (2011), while Turner \& Corlett (1996) stressed that fragments

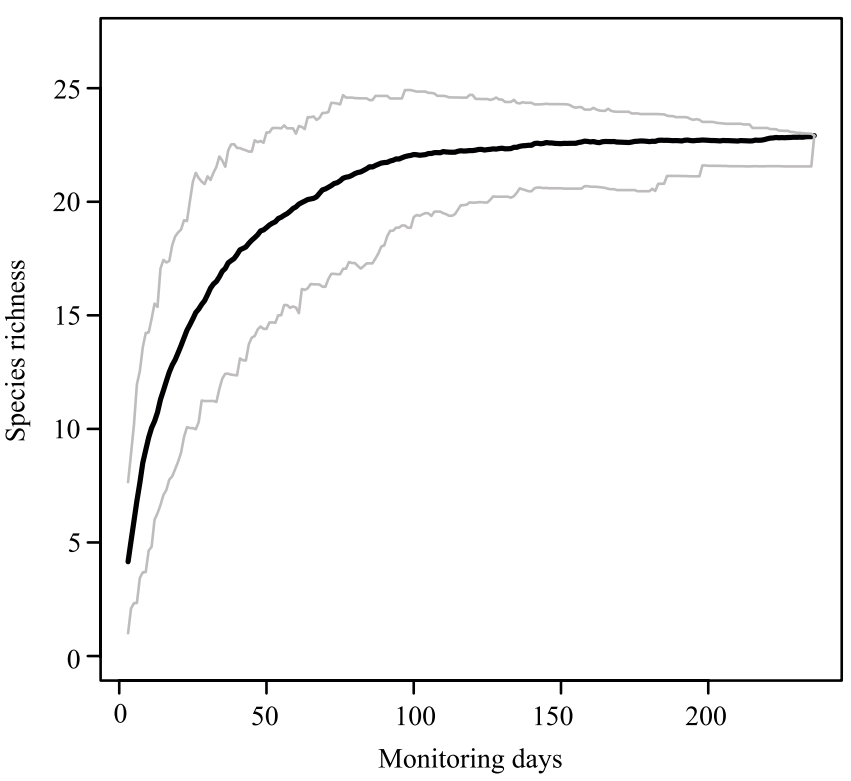

Figure 2. Ten camera traps were used to survey nonflying mammals heavier than one kilogram, at two farms in the westernmost portion of the Atlantic forest in Brazil, from April 10 to August 01, 2014. Solid black line: number of native species expected with the increment of days of monitoring. Grey lines: upper and lower 95\% confidence interval of the estimates. 
are better than nothing. However, the results of the present study represent a specific point in time, and population trends of native species - as well as species richness - may have been negative over the last few decades. The persistence of species such as marsh deer, tapir, and white-lipped peccaries is surprising in a landscape with conditions such as those of the study areas. It is still unknown what effects the invasive wild boar have had on native wildlife and their habitat, but given the conspicuous impacts on the vegetation along the banks of streams and rivers, changes in its quality are likely to have negative impacts on native species.

The introduced wild boar and the native tapir had the largest relative biomass/effort index among the photographed mammals. Pooled together, they represented about $94.5 \%$ of the total biomass/effort index of all recorded species, and most of native species showed a negligible relative biomass/effort index (Table 1).

Although the invasion of wild boars is relatively recent in Mato Grosso do Sul state (Deberdt \& Scherer, 2007), their hybrids have successfully established populations in the agroecosystems (Pedrosa et al., 2015), and feral hogs already dominate the relative biomass index of the mammal community in the study area. Wildlife in Brazil is protected by law, but as feral hogs are known to cause environmental damage (Hegel \& Marini, 2013) and economic losses, Ibama - the Brazilian agency for environmental protection, established regulations allowing actions for their population control under certain circumstances (Ibama 2013). However, experiments in other countries have shown that effective control can be difficult and costly (Morrison et al., 2007), although eradication has been successful in island environments (Parkes et al., 2010).

Table 1. Conservation status of mammals heavier than one kilogram, number of pictures per species (n), number of pictures per 100 days of camera use (n/effort), body mass, mean group size (group size), and relative biomass/effort index (\% biomass), recorded by camera traps at two farms in the southern Mato Grosso do Sul state, Brazil, from April to December 2014.

\begin{tabular}{|c|c|c|c|c|c|c|c|c|}
\hline \multirow[t]{2}{*}{ Species } & \multirow[t]{2}{*}{ Common name } & \multicolumn{2}{|c|}{ Status $^{(1)}$} & \multirow[t]{2}{*}{$\mathrm{n}$} & \multirow[t]{2}{*}{$\mathrm{n} / \mathrm{effort}$} & \multirow{2}{*}{$\begin{array}{c}\text { Body } \\
\operatorname{mass}(\mathrm{kg})\end{array}$} & \multirow{2}{*}{$\begin{array}{c}\text { Group } \\
\text { size }\end{array}$} & \multirow{2}{*}{$\begin{array}{c}\% \\
\text { Biomass }\end{array}$} \\
\hline & & Brazilian list & IUCN red list & & & & & \\
\hline Sus scrofa & Wild boar & - & - & 667 & 32.58 & 50.0 & 8.0 & 68.91 \\
\hline Tapirus terrestris & Brazilian tapir & VU & $\mathrm{VU}$ & 512 & 27.31 & 177.2 & 1.0 & 25.58 \\
\hline Tayassu pecari & White-lipped peccary & VU & $\mathrm{VU}$ & 5 & 0.37 & 29.3 & 55.0 & 3.17 \\
\hline Myrmecophaga tridactyla & Giant anteater & $\mathrm{VU}$ & VU & 42 & 2.90 & 32.0 & 1.0 & 0.49 \\
\hline Hydrochoerus hydrochaeris & Capybara & - & $\mathrm{LC}$ & 6 & 0.37 & 43.0 & 5.8 & 0.49 \\
\hline Pecari tajacu & Collared peccary & - & $\mathrm{LC}$ & 25 & 1.41 & 19.4 & 3.3 & 0.48 \\
\hline Blastocerus dichotomus & Marsh deer & VU & VU & 8 & 0.59 & 108.6 & 1.0 & 0.34 \\
\hline Cerdocyon thous & Crab-eating fox & - & $\mathrm{LC}$ & 44 & 2.90 & 6.6 & 2.0 & 0.20 \\
\hline Puma concolor & Puma & VU & $\mathrm{LC}$ & 8 & 0.60 & 35.4 & 1.0 & 0.11 \\
\hline Leopardus pardalis & Ocelot & - & $\mathrm{LC}$ & 27 & 1.86 & 7.0 & 1.0 & 0.07 \\
\hline Dasyprocta azarae & Azara's agouti & - & DD & 19 & 1.26 & 2.7 & 1.0 & 0.02 \\
\hline Dasypus novemcinctus & Nine-banded armadillo & - & $\mathrm{LC}$ & 16 & 1.04 & 4.1 & 1.0 & 0.02 \\
\hline Tamandua tetradactyla & Southern tamandua & - & $\mathrm{LC}$ & 8 & 0.52 & 6.2 & 1.0 & 0.02 \\
\hline Nasua nasua & South American coati & - & $\mathrm{LC}$ & 3 & 0.22 & 3.2 & 6.6 & 0.02 \\
\hline Sylvilagus brasiliensis & Tapeti & - & $\mathrm{LC}$ & 19 & 1.41 & 1.0 & 1.0 & 0.01 \\
\hline Euphractus sexcinctus & Yellow armadillo & - & $\mathrm{LC}$ & 6 & 0.37 & 4.7 & 1.0 & 0.01 \\
\hline Cuniculus paca & Spotted paca & - & $\mathrm{LC}$ & 5 & 0.37 & 7.5 & 1.0 & 0.01 \\
\hline Eira barbara & Tayra & - & $\mathrm{LC}$ & 5 & 0.37 & 3.9 & 1.0 & 0.01 \\
\hline Procyon cancrivorus & Crab-eating raccoon & - & $\mathrm{LC}$ & 4 & 0.29 & 8.8 & 1.0 & 0.01 \\
\hline Mazama americana & Red brocket deer & - & DD & 1 & 0.07 & 28.9 & 1.0 & 0.01 \\
\hline Puma yagouaroundi & Jaguarundi & VU & $\mathrm{LC}$ & 4 & 0.30 & 3.0 & 1.0 & $<0.01$ \\
\hline Sapajus cay & Azara's capuchin & VU & $\mathrm{LC}$ & 3 & 0.22 & 3.3 & 1.0 & $<0.01$ \\
\hline Lontra longicaudis & Neotropical river otter & - & NT & 1 & 0.07 & 5.8 & 1.0 & $<0.01$ \\
\hline
\end{tabular}

${ }^{(1)}$ Brazilian list according to the Brazilian Ministry of Environment (Brasil, 2014) and the IUCN red list according to IUCN (2014). 
The probability of occupancy of a given habitat by wild boars $(\psi=0.75)$ and by dogs $(\psi=0.71)$ was similar. In addition, the analysis of occupancy indicated that wild boars and dogs did not avoid each other in space $(\varphi=0.95)$, occupying the same habitats. The $r$ and $p$ values were the same for both species $(p=0.26$; $\mathrm{r}=0.26$ ), suggesting that the detection of one species is not affected by the presence of the other (Mackenzie et al., 2002). However, alternatively, one may argue that this result could be the effect of the different periods of activity of these species, or due to the temporal scale used in the study. In fact, although they showed some activity during daylight hours, wild boars were clearly crepuscular to nocturnal, with their maximum activity occurring at around midnight, gradually declining as sunrise approached (Figure 3). In contrast, the dogs were active during the daytime, showing a bimodal pattern, with a maximum between 08:00 and 09:00 h, decreasing between 12:00 and 14:00 h, and reaching a second maximum around 16:00 h. Some activity was recorded in the evening, but decreased abruptly from 22:00 $\mathrm{h}$ on. Overlapping activity between wild boars and dogs was relatively low (proportion $=0.33$ ) in the $95 \%$ activity isopleths, and negligible in the $50 \%$ isopleths $(<0.01)$.

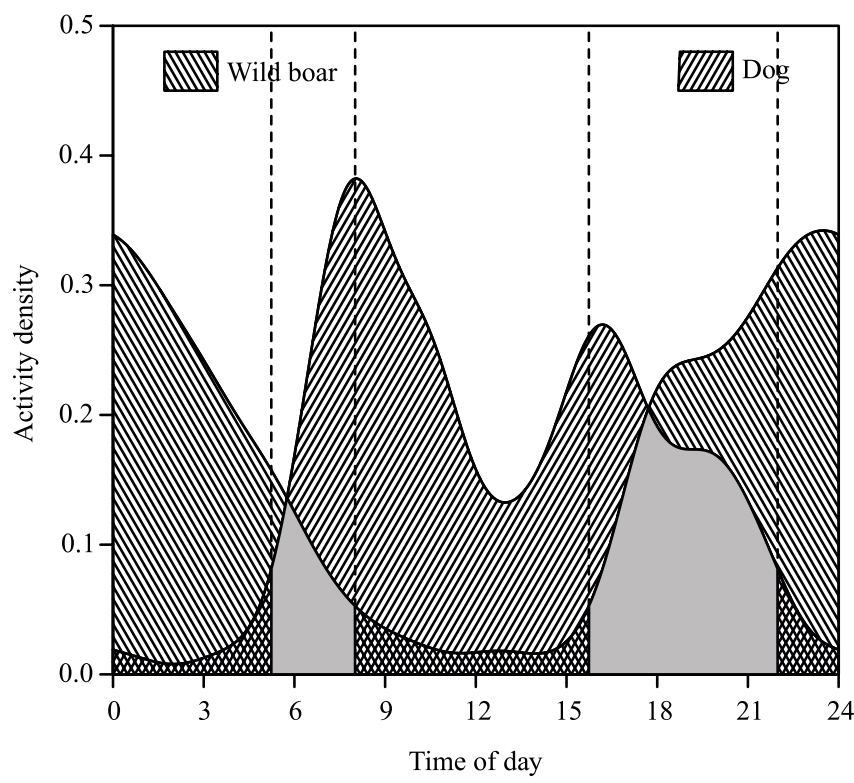

Figure 3. Activity overlap between wild boars and domestic dogs in agroecosystems in western Atlantic Forest, in the municipality of Rio Brilhante, Mato Grosso do Sul state, Brazil, from April to December 2014. Overlapping sections of the $95 \%$ activity isopleths are displayed in grey.
In Mato Grosso do Sul state, farmers are confident that dogs can control wild boar populations, or at least protect their crops during critical periods. However, the findings indicate that the hogs are successfully avoiding the dogs in time, and international experience suggests that more effective actions will be required for these tasks. Shooting the hogs according to a sport hunting system would probably be ineffective, and governance would be required to deal with all the aspects involved in the control of hog invasions, their environmental impacts, and health risks. Brazil has lost the hunting tradition after 50 years of the ban imposed by the Law no 5197/1967 (Brasil, 1967); however, poaching has been the "rule" everywhere in the country since then. The outcome of this historic decision is the lack of governance for hunting, and the lack of public education and understanding of the principles of sustainable use of wildlife. Recovering the institutional capability to deal with hunting to control wild boar populations would be essential, but raising public awareness and understanding is mandatory.

\section{Conclusions}

1. Despite the extensive change in land cover, 22 native species $(50 \%$ of the total number of medium and large-sized terrestrial mammals known to occur in Mato Grosso do Sul) are registered in the studied area.

2. Wild boars show a high biomass in the study area, which indicates the high ability of the species to invade those areas, and the low efficiency of control method adopted by local farmers.

3. The use of dogs to prevent crop damage is not a good strategy in the study area; although wild boars and dogs occupy the same habitats, they do it in different times of day.

\section{Acknowledgments}

To Conselho Nacional de Desenvolvimento Científico e Tecnológico (CNPq) and to Fundação de Apoio ao Desenvolvimento do Ensino, Ciência e Tecnologia do Estado do Mato Grosso do Sul (Fundect), for financial support (grant Pronex 006/2015); to CNPq, for fellowship to the eighth author (number 308934/2017-2) and scholarship to the first author; to Fundect, for financial support and scholarship to the second author; to Embrapa (project SEG 02.12.01.014.00.00), for financial support; to 
the owners and employees of the Carro de Boi and Gramado farms, for allowing access to the study areas and providing logistic support during field activities; and to Dr. Carlos Salvador, for reviewing an earlier version of the manuscript.

\section{References}

ABIMILHO. Associação Brasileira das Indústrias do Milho. Estatísticas: produção mundial. 2019. Available at: <http://www. abimilho.com.br/estatisticas/producao-mundial $>$. Accessed on: June 282019.

BARBO, C.V.S.; CARNIELLI, A.; PÖTTKER, D.; SALVADORI, J.R.; SILVA, C.M. da; SONEGO, O.R.; FERNANDES, F.M. Recomendações técnicas para a cultura da soja: região da Grande Dourados - safra 1980/81. Dourados: Embrapa-Uepae Dourados, 1980. 53p. (Embrapa-Uepae Dourados. Circular técnica, 2).

BRASIL. Lei $n^{\circ}$ 5.197, de 3 de janeiro de 1967. Dispõe sobre a proteção à fauna e dá outras providências. Diário Oficial da União, 5 jan. 1967. Seção 1, p.177.

BRASIL. Ministério do Meio Ambiente. Portaria no 444, de 17 de dezembro de 2014. [Lista Nacional Oficial de Espécies da Fauna Ameaçadas de Extinção]. Diário Oficial da União, 18 dez. 2014. Seção 1, p.121-126.

CÁCERES, N.C.; CARMIGNOTTO, A.P.; FISCHER, E.; SANTOS, C.F. Mammals from Mato Grosso do Sul, Brazil. Check List, v.4, p.321-335, 2008. DOI: https://doi.org/10.15560/4.3.321.

CASSANO, C.R.; BARLOW, J.; PARDINI, R. Large mammals in an agroforestry mosaic in the Brazilian Atlantic Forest. Biotropica, v.44, p.818-825, 2012. DOI: https://doi.org/10.1111/ j.1744-7429.2012.00870.x.

CROSBY, A.W. Imperialismo ecológico: A expansão biológica da Europa 900-1900. São Paulo: Companhia de Bolso, 1993. 376p.

CULlEN JR, L.; BODMER, R.E.; PÁDUA, C.V. Effects of hunting in habitat fragments of the Atlantic forests, Brazil. Biological Conservation, v.95, p.49-56, 2000. DOI: https://doi.org/10.1016/S0006-3207(00)00011-2.

DEBERDT, A.J.; SCHERER, S.B. O javali asselvajado: ocorrência e manejo da espécie no Brasil. Natureza \& Conservação, v.5, p.31-44, 2007.

DESBIEZ, A.L.J.; KEUROGHLIAN, A.; PIOVEZAN, U.; BODMER, R.E. Invasive species and bushmeat hunting contributing to wildlife conservation: the case of feral pigs in a Neotropical wetland. Oryx, v.45, p.78-83, 2011. DOI: https://doi.org/10.1017/S0030605310001304.

DOTTA, G.; VERDADE, L.M. Medium to large-sized mammals in agricultural landscapes of South-Eastern Brazil. Mammalia, v.75, p.345-352, 2011. DOI: https://doi.org/10.1515/ MAMM.2011.049.

EISENBERG, J.F.; REDFORD, K.H. Mammals of the Neotropics: the central neotropics: volume 3: Ecuador, Peru, Bolivia, Brazil. Chicago: University of Chicago, 1999. 610p.
EMMONS, L.H.; FEER, F. Neotropical rainforest mammals: a field guide. Chicago: University of Chicago, 1990. 281p.

GOOGLE EARTH PRO. Google, Inc. Mountain View California. 2013. Available at: <https://www.google.com/earth/ download/gep/agree.html>. Accessed on: Aug. 152015.

HEGEL, C.G.Z.; MARINI, M.A. Impact of the wild boar, Sus scrofa, on a fragment of Brazilian Atlantic Forest. Neotropical Biology and Conservation, v.8, p.17-24, 2013. DOI: https://doi.org/10.4013/nbc.2013.81.03.

HINES, J.E. PRESENCE2: Software to estimate patch occupancy and related parameters. USGS-PWRC. 2006. Available at: $<$ https:// www.mbr-pwrc.usgs.gov/software/doc/presence/presence.html $>$. Accessed on: Nov. 172015.

HIROTA, M.M. Atlas dos remanescentes florestais da Mata Atlântica: relatório técnico: período 2017-2018. São Paulo: Fundação SOS Mata Atlântica, 2019.

IBAMA. Instrução Normativa $n^{\circ}$ 3, de 31 de janeiro de 2013. Decreta a nocividade do Javali e dispõe sobre o seu manejo e controle. Diário Oficial da União, 1 fev. 2013. Seção 1, p.88-89.

IUCN. The IUCN Red List of Threatened Species. Version 2014.3. 2014. Available at: $<$ http://www.iucnredlist.org $>$. Accessed on: Aug. 232016.

LONG, J.L. Introduced mammals of the world: their history, distribution and influence. Collingwood: CSIRO, 2003. 589p. DOI: https://doi.org/10.1071/9780643090156.

LOWE, S.; BROWNE, M.; BOUDJELAS, S.; DE POORTER, M. 100 of the world's worst invasive alien species: a selection from the global invasive species database. Gland: ISSG, 2000. 12p.

MACKENZIE, D.I.; NICHOLS, J.D.; LACHMAN, G.B.; DROEGE, S.; AROYLE, J.A.; LANGTIMM, C.A. Estimating site occupancy rates when detection probabilities are less than one. Ecology, v.83, p.2248-2255, 2002.

MORRISON, S.A.; MCDONALD, N.; WALKER, K.; LOZIER, L.; SHAW, M.R.Facing the dilemma at eradication's end: uncertainty of absence and the Lazarus effect. Frontiers Ecology and the Environment, v.5, p.271-276, 2007.

OIE. World Organization for Animal Health. Resolutions adopted by the World Assembly of Delegates of the OIE during its 81st General Session. In: GENERAL SESSION OF THE WORLD ASSEMBLY OF DELEGATES OF THE WORLD ORGANISATION FOR ANIMAL HEALTH (OIE), 81., 2013, Paris. Final report 2013. Paris: OIE, 2013. p.123-190.

OKSANEN, J.; BLANCHET, F.G.; FRIENDLY, M.; KINDT, R.; LEGENDRE, P.; MCGLINN, D.; MINCHIN, P.R.; O'HARA, R.B.; SIMPSON, G.L.; SOLYMOS, P.; STEVENS, M.H.H.; SZOECS, E.; WAGNER, H. Vegan: community ecology package. R package version 2.4-0. 2016. Available at: <https://CRAN.Rproject.org/package=vegan $>$. Accessed on: Jan. 232016 .

OLIVEIRA, H. de; URCHEI, M.A.; FIETZ, C.R. Aspectos físicos e socioeconômicos da bacia hidrográfica do rio Ivinhema. Dourados: Embrapa Agropecuária Oeste, 2000. 53p. (Embrapa Agropecuária Oeste. Documentos, 25). 
OLIVEIRA-SANTOS, L.G.R.; DORAZIO, R.M.; TOMAS, W.M.; MOURÃO, G.; FERNANDEZ, F.A.S. No evidence of interference competition among the invasive feral pig and two native peccary species in a Neotropical wetland. Journal of Tropical Ecology, v.27, p.557-561, 2011. DOI: https://doi.org/10.1017/S026646741100023X.

OLIVEIRA-SANTOS, L.G.R.; ZUCCO, C.A.; AGOSTINELLI, C. Using conditional circular kernel density functions to test hypotheses on animal circadian activity. Animal Behaviour, v.85, p.269-280, 2013. DOI: https://doi.org/10.1016/j. anbehav.2012.09.033.

PARKES, J.P.; RAMSEY, D.S.L.; MACDONALD, N.; WALKER, K.; MCKNIGHT, S.; COHEN, B.S.; MORRISON, S.A. Rapid eradication of feral pigs (Sus scrofa) from Santa Cruz Island, California. Biological Conservation, v.143, 634-641, 2010. DOI: https://doi.org/10.1016/j.biocon.2009.11.028.

PEDROSA, F.; SALERNO, R.; PADILHA, F.V.B.; GALETTI, M. Current distribution of invasive feral pigs in Brazil: economic impacts and ecological uncertainty. Natureza \& Conservação, v.13, p.84-87, 2015. DOI: https://doi.org/10.1016/j. ncon.2015.04.005.
PIMENTEL, D.; ZUNIGA, R.; MORRISON, D. Update on the environmental and economic costs associated with alien-invasive species in the United States. Ecological Economics, v.52, p.273288, 2005. DOI: https://doi.org/10.1016/j.ecolecon.2004.10.002.

R CORE TEAM. R: A language and environment for statistical computing. Vienna: R Foundation for Statistical Computing, 2016. Available at: <https://www.R-project.org/>. Accessed on: Jan. 52016.

REDFORD, K.H.; EISENBERG, J.F. Mammals of the Neotropics: the southern cone: volume 2: Chile, Argentina, Uruguay, Paraguay. Chicago: University of Chicago, 1992. 440p.

TURNER, I.M.; CORLETT, R.T. The conservation value of small, isolated fragments of lowland tropical rain forest. Trends in Ecology \& Evolution, v.11, p.330-333, 1996. DOI: https://doi.org/10.1016/0169-5347(96)10046-X.

ZONEAMENTO Ecológico Econômico do Estado de Mato Grosso do Sul. 2009. Anexo I da Lei no 3.839, de 28 de dezembro de 2009. Available at: <http://193.43.36.109/docs/pdf/bra116233AnnexI. pdf $>$. Accessed on: June 172019. 